Article

\title{
Isocitric Acid Production from Ethanol Industry Waste by Yarrowia lipolytica
}

\author{
Svetlana V. Kamzolova *(D), Vladimir A. Samoilenko, Julia N. Lunina and Igor G. Morgunov \\ G.K. Skryabin Institute of Biochemistry and Physiology of Microorganisms, Pushchino Center for Biological \\ Research of the Russian Academy of Sciences, Prospect Nauki 5, Pushchino, 142290 Moscow, Russia; \\ samva@rambler.ru (V.A.S.); luninaju@rambler.ru (J.N.L.); morgunovs@rambler.ru (I.G.M.) \\ * Correspondence: kamzolova@rambler.ru; Tel.: +7-926-414-5620
}

Citation: Kamzolova, S.V.;

Samoilenko, V.A.; Lunina, J.N.;

Morgunov, I.G. Isocitric Acid

Production from Ethanol Industry

Waste by Yarrowia lipolytica.

Fermentation 2021, 7, 146. https://

doi.org/10.3390/fermentation7030146

Academic Editor: Ronnie G. Willaert

Received: 15 July 2021

Accepted: 31 July 2021

Published: 4 August 2021

Publisher's Note: MDPI stays neutral with regard to jurisdictional claims in published maps and institutional affiliations.

Copyright: (c) 2021 by the authors. Licensee MDPI, Basel, Switzerland. This article is an open access article distributed under the terms and conditions of the Creative Commons Attribution (CC BY) license (https:// creativecommons.org/licenses/by/ $4.0 /)$.
Abstract: There is ever increasing evidence that isocitric acid can be used as a promising compound with powerful antioxidant activity to combat oxidative stress. This work demonstrates the possibility of using waste product from the alcohol industry (so-called ester-aldehyde fraction) for production of isocitric acid by yeasts. The potential producer of isocitric acid from this fraction, Yarrowia lipolytica VKM Y-2373, was selected by screening of various yeast cultures. The selected strain showed sufficient growth and good acid formation in media with growth-limiting concentrations of nitrogen, sulfur, phosphorus, and magnesium. A shortage of $\mathrm{Fe}^{2+}$ and $\mathrm{Ca}^{2+}$ ions suppressed both Y. lipolytica growth and formation of isocitric acid. The preferential synthesis of isocitric acid can be regulated by changing the nature and concentration of nitrogen source, $\mathrm{pH}$ of cultivation medium, and concentration of ester-aldehyde fraction. Experiments in this direction allowed us to obtain $65 \mathrm{~g} / \mathrm{L}$ isocitric acid with a product yield $\left(\mathrm{Y}_{\mathrm{ICA}}\right)$ of $0.65 \mathrm{~g} / \mathrm{g}$ in four days of cultivation.

Keywords: microbial synthesis; yeast; isocitric acid; Yarrowia lipolytica; waste from alcohol industry; ester-aldehyde fraction; optimization

\section{Introduction}

Over the past two decades, isocitric acid has attracted the attention of researchers as a promising compound for the pharmaceutical and food industry [1-11]. The antioxidant activity of microbially produced isocitric acid exceeds that of the classic antioxidant ascorbic acid [7]. Isocitric acid beneficially influences the spatial memory of intact laboratory rats and those intoxicated with heavy metals. It reduces the number of inadequate conditioned reactions and promotes the development of skills that meet new spatial conditions $[8,10]$.

Despite many positive properties, isocitric acid is still rarely used due to its difficult production. Chemical synthesis gives a mixture of four stereoisomers of isocitric acid: threo$\mathrm{D}_{\mathrm{S}^{-}}$, threo-Ls-, erythro-Ds-, and erythro-Ls- [12], of which only threo-D $\mathrm{S}^{-}$or $(2 R, 3 S)$-isocitric acid (according to IUPAC Organic Nomenclature) is a metabolite of the tricarboxilic acid (TCA) cycle used by all aerobic organisms. It is this isomer that is commonly called isocitric acid (ICA). At the moment, the technology of separation of mixtures of stereoisomers has not been developed. In other words, chemical synthesis cannot be used for production of pharmacopoeial quality ICA. As for the production of naturally occurring ICA with the aid of the specially cultivated plant Sedum spectabile, the cost of ICA produced by this method is too high (USD 750 per $1 \mathrm{~g}$ ICA) [8].

Alternatively, ICA can be produced using the yeast Yarrowia lipolytica [3,11]. The representatives of this species are nompathogenic and have a status of GRAS (generally regarded as safe). They do not form mycotoxins and potentially allergenic spores during cultivation. Their metabolites are not toxic, mutagenic or clastogenic and hence can be used as food additives [13,14]. The microbial synthesis of ICA is relatively simple, fast, and cheap. As a result, the produced ICA becomes affordable and cost-effective for wide application. 
The existing microbial methods of ICA production suggest the use of purified substrates as sources of carbon and energy. The range of such substrates includes ethanol $[7,8,15,16]$, rapeseed oil [17-19], sunflower oil [1,3,4,20], glucose [21-24] and glycerol [21-25]. Besides, researchers used cheap wastes from biodiesel production $[10,26,27]$. In the works cited above, it is emphasized that the main condition of ICA production is the limitation of yeast growth by nitrogen source and the excess of carbon source. In all cases, ICA was synthesized together with citric acid (CA).

An urgent task is to expand the list of growth substrates used, increase the yield of organic acids, and reduce the cost of the final product. When developing the process of ICA production by yeast $Y$. lipolytica, we decided to use waste from the alcohol industry known as ester-aldehyde fraction (EAF).

EAF is formed as an ethanol distillation byproduct and contains some amount of ethanol and a range of volatile substances with a specific color and odor. These substances include aldehydes, methanol, esters, and carboxylic acids. Despite the low content of these substances, they are harmful, especially aldehydes, and cause a strong irritant effect on the mucosa of the eyes and upper respiratory tract. As a result, EAF is widely used only in the paint and varnish industry. At the same time, the main component of EAF, ethanol, is readily utilized by the yeast $Y$. lipolytica in concentrations up to $3 \mathrm{wt} \%$ [28] and may serve as an excellent substrate for the biosynthetic production of ICA $[7,8,15,16]$. To date, EAF has not been investigated as a potential source of carbon and energy for microbial ICA production.

The aim of this work was to study the possibility of using EAF for ICA production with the aid of yeasts, to select a promising producer, and to determine the cultivation conditions that provide an enhanced and directed synthesis of ICA.

\section{Materials and Methods}

Experiments were carried out with 35 wild strains of various yeast species and genera obtained from the All-Russian Collection of Microorganisms (VKM), as well as with the mutant and recombinant strains of Y. lipolytica from the culture collection of the laboratory of aerobic microbial metabolism of the Institute of Biochemistry and Physiology of Microorganisms of Russian Academy of Sciences. The mutant strain Y. lipolytica UV/NNG was derived from the wild strain Y. lipolytica VKM Y-2373 by ultraviolet irradiation (4 min) and treatment with N-methyl-N'-nitro-N-nitrosoguanidine $(50 \mu \mathrm{g} / \mathrm{mL})$ [17]. The recombinant strain Y. lipolytica ACO1 (no. 20) with the superexpressed gene of aconitate hydratase was derived from the wild strain Y. lipolytica 607 [18]. All strains under study were maintained at $+4{ }^{\circ} \mathrm{C}$ on Reader agar with paraffin and re-cultured each 3 months.

All chemicals were of analytical grade (Mosreactiv, Russia). EAF represented a lightyellow liquid with a persistent unpleasant odor. EAF contained ethanol ( $90 \mathrm{vol} \%)$, aldehydes $(0.5 \mathrm{~g} / \mathrm{L}$ in terms of acetaldehyde), esters $(0.4 \mathrm{~g} / \mathrm{L}$ in terms of ethylacetate), and methanol (1 vol\%).

To select ICA producers, yeast strains were cultivated at $29{ }^{\circ} \mathrm{C}$ on a shaker $(130 \mathrm{rpm})$ in large tubes ( $2 \mathrm{~cm}$ in diameter and $20 \mathrm{~cm}$ long) with $5 \mathrm{~mL}$ of Reader medium with a 10 -fold reduced content of ammonium sulfate. This medium contained (g/L): $\left(\mathrm{NH}_{4}\right)_{2} \mathrm{SO}_{4}$, 0.3; $\mathrm{MgSO}_{4} \cdot 7 \mathrm{H}_{2} \mathrm{O}, 0.7 ; \mathrm{Ca}\left(\mathrm{NO}_{3}\right)_{2} \cdot 4 \mathrm{H}_{2} \mathrm{O}, 0.4 ; \mathrm{NaCl}, 0.5 ; \mathrm{KH}_{2} \mathrm{PO}_{4}, 1.0$; and $\mathrm{K}_{2} \mathrm{HPO}_{4}, 0.2$. The medium was supplemented with yeast extract "Difco" (0.5 g/L) and Burkholder microelement solution of the following composition (mg/L): $\mathrm{KJ}, 0.1 ; \mathrm{B}^{3+}, 0.01 ; \mathrm{Mn}^{2+}, 0.01$; $\mathrm{Zn}^{2+}, 0.01 ; \mathrm{Cu}^{2+}, 0.01 ; \mathrm{Mo}^{2+}, 0.01$; and $\mathrm{Fe}^{2+}, 0.05$. EAF was added in portions $(2 \mathrm{~g} / \mathrm{L})$ to the concentration of $20 \mathrm{~g} / \mathrm{L}$. Cultivation lasted 4 days.

To study the effect of growth-limiting components of cultivation media, the strain $Y$. lipolytica VKM Y-2373 was cultivated at $29^{\circ} \mathrm{C}$ on the shaker $(130 \mathrm{rpm})$ in $750-\mathrm{mL}$ Erlenmeyer flasks with $50 \mathrm{~mL}$ of a modified Reader medium with the concentrations of $\mathrm{KH}_{2} \mathrm{PO}_{4}$, $\mathrm{K}_{2} \mathrm{HPO}_{4}$, and sulfur were reduced 100-fold; the concentrations of $\mathrm{MgSO}_{4}$ and calcium were reduced 500-fold; and the concentration of iron was reduced by 50 times in comparison with the original Reader medium. EAF was added in portions $(2 \mathrm{~g} / \mathrm{L})$ to the concentration 
of $20 \mathrm{~g} / \mathrm{L}$. During cultivation, $\mathrm{pH}$ was maintained automatically at a level of 6.0 by adding the necessary amount of a sterile solution of $\mathrm{NaOH}$. Cultivation lasted 4 days.

Experiments on the influence of nitrogen source were carried out in the flasks as described above. Various nitrogen sources were added in the concentration of $63 \mathrm{mg} / \mathrm{L}$ (in terms of nitrogen). Experiments on the effect of $\mathrm{pH}$ were described below in details in the Results section.

To study the effect of EAF concentration and dynamics of ICA formation, Y. lipolytica VKM Y-2373 was cultivated in a 10-1 ANKUM-2M fermentor (IBP RAS, Pushchino, Russia) with the culture volume of $5 \mathrm{~L}$. The cultivation temperature was $29^{\circ} \mathrm{C}$, the concentration of dissolved oxygen was $55-60 \%$ (of air saturation), $\mathrm{pH}$ was 6.0, and agitation was $800 \mathrm{rpm}$. The modified Reader medium contained (g/L): $\left(\mathrm{NH}_{4}\right)_{2} \mathrm{SO}_{4}, 3.0 ; \mathrm{MgSO}_{4} \cdot 7 \mathrm{H}_{2} \mathrm{O}, 1.4$; $\mathrm{Ca}\left(\mathrm{NO}_{3}\right)_{2}, 0.8 ; \mathrm{NaCl}, 0.5 ; \mathrm{KH}_{2} \mathrm{PO}_{4}, 2.0 ; \mathrm{K}_{2} \mathrm{HPO}_{4}, 0.2 ;$ double volume of Burkholder solution. The concentration of $\mathrm{Zn}^{2+}$ and $\mathrm{Fe}^{2+}$ was increased to 0.3 and $1.2 \mathrm{mg} / \mathrm{L}$, respectively. Yeast autolysate was added to the fermentor before inoculation at a concentration of $6.3 \mathrm{~mL} / \mathrm{L}$. EAF was added in portions (from 1 to $10 \mathrm{~g} / \mathrm{L}$ ) at the moments when oxygen concentration in the fermentor fell by $10 \%$ (of air saturation) from the basal level. Cultivation lasted 4 days.

Yeast growth was followed by measuring the biomass dry weight: $1-3 \mathrm{~mL}$ of the culture broth was filtered through a membrane filter; yeast cells were washed with $\mathrm{H}_{2} \mathrm{O}$ and dried under vacuum at $110^{\circ} \mathrm{C}$ to the constant weight.

Concentration of $\mathrm{NH}_{4}{ }^{+}$was determined potentiometrically with an Ecotest-120 ionometer using an Ekom-NH4 electrode (Econix, Moscow, Russia).

Ethanol and impurities in the EAF were determined by gas-liquid chromatography on a Chrom-5 chromatograph (Laboratory Instruments, Praha, Czech Republic) with a flameionization detector using a glass column $(200 \times 0.3 \mathrm{~mm})$ packed with $15 \%$ Reoplex-400 on Chromaton N-AW $(0.16-0.20 \mathrm{~mm})$ at a column temperature of $65^{\circ} \mathrm{C}$; argon was used as a carrier gas.

To analyze organic acids, the culture broth was centrifuged $\left(8000 \times g, 20^{\circ} \mathrm{C}, 3 \mathrm{~min}\right)$; $1 \mathrm{~mL}$ of the supernatant was diluted with an equal volume of $8 \% \mathrm{HClO}_{4}$ and the concentration of organic acids was measured on an HPLC chromatograph (LKB, Sweden) equipped with an Inertsil ODS-3 reversed-phase column $(250 \times 4 \mathrm{~mm}$, Elsiko, Moscow, Russia) at $210 \mathrm{~nm} ; 20 \mathrm{mM}$ phosphoric acid was used as a mobile phase with a flow rate of $1.0 \mathrm{~mL} \cdot \mathrm{min}^{-1}$; the column temperature was maintained at $35^{\circ} \mathrm{C}$. Quantitative determination of acids was carried out with the help of calibration curves constructed with the use of appropriate standards (Sigma-Aldrich, St. Louis, MO, USA). Moreover, diagnostic kits (Roche Diagnostics GmbH, Mannheim, Germany) were used for the assay of ICA and CA concentrations. The determination of ICA was based on the measurement of NADPH produced during the conversion of ICA to $\alpha$-ketoglutarate, a reaction catalyzed by isocitrate dehydrogenase. The determination of CA was based on the measurement of NADH produced during the conversion of CA to oxaloacetate and its decarboxylation product, pyruvate, and subsequent conversion to L-malate and L-lactate. Reactions were catalyzed by citrate lyase, malate dehydrogenase and L-lactate dehydrogenase.

The calculation of production parameters, such as the product yield $\left(\mathrm{Y}_{\mathrm{ICA}}\right)$, the specific growth rate $(\mu)$, the specific rate of ICA synthesis ( IICA $_{\text {IC }}$, and volume productivity (QICA), have been described earlier $[20,26]$.

The results presented in this paper are the means of experiments performed in triplicate or quadruplicate. Each measurement was repeated twice. Standard deviation did not exceed $10 \%$. The product yield $\left(\mathrm{Y}_{\mathrm{ICA}}\right)$, the specific rate of synthesis $\left(\mathrm{q}_{\mathrm{ICA}}\right)$, and volume productivity $\left(\mathrm{Q}_{\mathrm{ICA}}\right)$ were calculated based on average values of ICA.

\section{Results}

\subsection{Selection of ICA Producer}

The quantitative composition of the metabolites excreted from the cells of various yeast strains when their growth was limited by nitrogen shortage is shown in Table 1. As 
seen from this table, most of the strains studied (26 from 35) excreted ICA in amounts from 0.06 to $5.51 \mathrm{~g} / \mathrm{L}$ when they grew on EAF under nitrogen deficiency. Four of these strains produced ICA in small amounts (below $0.1 \mathrm{~g} / \mathrm{L}$ ); 12 strains produced it in amounts from 0.1 to $0.5 \mathrm{~g} / \mathrm{L} ; 2$ strains, from 0.5 to $1 \mathrm{~g} / \mathrm{L} ; 3$ strains, from 1 to $2 \mathrm{~g} / \mathrm{L}$; and 2 strains, from 2 to $3 \mathrm{~g} / \mathrm{L}$. The maximum ICA-producing ability was exhibited by three strains, Y. lipolytica VKM Y-2373, Y. lipolytica UV/NNG, and Y. lipolytica ACO1 no. 20 (5.51, 4.61, and $3.73 \mathrm{~g} / \mathrm{L}$, respectively). Besides ICA, the yeast strains excreted other metabolites, such as citric acid (CA), acetic acid (AA), $\alpha$-ketoglutaric acid (KGA), succinic acid (SA), malic acid (MA), and fumaric acid (FA). Most strains of the species Y. lipolytica excreted mainly ICA (from 32.3 to $53.5 \%$ of the total amount of acids), the maximum relative content of ICA ( $53.5 \%$ of the total amount of acids) being demonstrated by the wild strain Y. lipolytica VKM Y-2373. It is this strain that was chosen for further investigations as a promising producer of ICA from EAF.

Table 1. Acid production by yeast in the medium containing EAF as a carbon source under nitrogen limitation.

\begin{tabular}{|c|c|c|c|c|c|c|c|c|}
\hline \multirow{2}{*}{ Strain } & \multicolumn{7}{|c|}{ Acids $(g / L)$} & \multirow{2}{*}{ ICA $(\%$ of Total Acids } \\
\hline & ICA & AA & CA & KGA & SA & MA & FA & \\
\hline $\begin{array}{c}\text { Aciculoconidium aculeatum VKM } \\
\text { Y-1301 }\end{array}$ & 0 & 0 & 0.11 & 0 & 0 & 0.11 & 0.06 & - \\
\hline Babjeviella inositovora VKM Y-2494 & 0.10 & 0.09 & 0.13 & 0.08 & 0 & 0.04 & 0.05 & 22.7 \\
\hline $\begin{array}{c}\text { Blastobotrys adeninivorans VKM } \\
\text { Y-2676 }\end{array}$ & 0 & 0.11 & 0.33 & 0.16 & 0 & 0.11 & 0.11 & - \\
\hline Candida intermedia & 0.08 & 0.12 & 0.01 & 0.12 & 0 & 0.12 & 0.12 & 17.8 \\
\hline C. saitoana 127 & 0.10 & 0 & 0.45 & 0.07 & 0 & 0.1 & 0.07 & 13.9 \\
\hline C. utilis VKM Y-33 & 0 & 0.14 & 1.05 & 0.42 & 0.32 & 0.45 & 0.10 & - \\
\hline C. zeylanoides VKM Y-14 & 0.50 & 0.12 & 1.0 & 0.10 & 0.32 & 0.44 & 0.07 & 20.2 \\
\hline C. zeylanoides VKM Y-2324 & 0.38 & 0.12 & 0.55 & 0.13 & 0.25 & 0.22 & 0.06 & 23.0 \\
\hline C. valida VKM Y-1493 & 0.14 & 0.12 & 0 & 0 & 0.52 & 0.12 & 0.01 & 15.6 \\
\hline Diutina catenulata VKM Y-5 & 0.15 & 0.15 & 0.21 & 1.50 & 0.33 & 0.62 & 0.08 & 5.1 \\
\hline D. rugosa VKM Y-67 & 0 & 0.14 & 0.15 & 0 & 0.2 & 0 & 0.07 & - \\
\hline $\begin{array}{c}\text { Kluyveromyces wickerhamii VKM } \\
\text { Y-589 }\end{array}$ & 0 & 0.62 & 0.18 & 0.08 & 0.21 & 0.10 & 0.05 & - \\
\hline Kregervanrija fluxuum VKM Y-240 & 0.31 & 0.11 & 0 & 0.10 & 0.32 & 0.15 & 0.08 & 31.3 \\
\hline Meyerozyma guilliermondii & 0.20 & 0.53 & 0.45 & 0.09 & 0.15 & 0.12 & 0.05 & 13.0 \\
\hline Pichia besseyi VKM Y-2084 & 0 & 0.12 & 0.43 & 0.45 & 0.40 & 0.32 & 0.03 & - \\
\hline P. media VKM Y-1381 & 0.20 & 0.10 & 0.40 & 0.10 & 0.33 & 0.10 & 0.04 & 16.3 \\
\hline P. membranifaciens VKM Y-292 & 0 & 0.13 & 0.15 & 0 & 0.13 & 0 & 0.07 & - \\
\hline $\begin{array}{c}\text { Sugiyamaella paludigena VKM } \\
\text { Y-2443 }\end{array}$ & 0.08 & 0.55 & 0 & 0.40 & 0.55 & 0.32 & 0.07 & 4.2 \\
\hline Torulaspora candida 420 & 0.10 & 0.45 & 0.32 & 0.10 & 0 & 0.10 & 0.08 & 9.3 \\
\hline T. globosa VKM Y-93 & 0.10 & 0.10 & 0 & 0.10 & 0.10 & 0.10 & 0.10 & 20.0 \\
\hline $\begin{array}{c}\text { Wickerhamomyces anomalus VKM } \\
\text { Y-118 }\end{array}$ & 0 & 0.15 & 0 & 0.10 & 0.43 & 0.12 & 0.07 & - \\
\hline Yarrowia lipolytica $12 \mathrm{a}$ & 0.15 & 0.15 & 0 & 0.09 & 0.52 & 0.15 & 0.06 & 14.2 \\
\hline Y. lipolytica VKM Y-47 & 0 & 0.10 & 0.52 & 0.45 & 0.40 & 0.30 & 0.10 & - \\
\hline Y. lipolytica 68 & 0.06 & 0.10 & 0.07 & 0.10 & 0.10 & 0.10 & 0.10 & 11.3 \\
\hline Y. lipolytica 69 & 1.11 & 0.15 & 0.92 & 0.50 & 0.35 & 0.41 & 0.12 & 32.3 \\
\hline Y. lipolytica VKM Y-57 & 1.42 & 0.10 & 0.72 & 0.07 & 0.35 & 0.21 & 0.06 & 49.5 \\
\hline Y. lipolytica VKM Y-2412 & 1.75 & 0.10 & 1.50 & 0.09 & 0.24 & 0.10 & 0.20 & 46.3 \\
\hline Y. lipolytica $374 / 4$ & 2.10 & 0.15 & 1.63 & 0.08 & 0.14 & 0.11 & 0.02 & 50.0 \\
\hline Y. lipolytica 571 & 0.55 & 0.10 & 0.30 & 0.10 & 0.10 & 0.10 & 0.10 & 44.0 \\
\hline Y. lipolytica 581 & 0.65 & 0.10 & 0.72 & 0.10 & 0.10 & 0.10 & 0.10 & 36.7 \\
\hline Y. lipolytica 585 & 0.06 & 0.08 & 0.10 & 0 & 0.30 & 0.10 & 0.08 & 9.4 \\
\hline Y. lipolytica 607 & 2.30 & 0.10 & 1.50 & 0.10 & 0.45 & 0.10 & 0.10 & 50.5 \\
\hline Y. lipolytica VKM-2373 & 5.51 & 0.5 & 4.24 & 0.10 & 0.13 & 0.12 & 0.08 & 53.5 \\
\hline Y. lipolytica UV/NNG & 4.61 & 1.17 & 3.18 & 1.15 & 0.12 & 0.10 & 0.10 & 44.6 \\
\hline Y. lipolytica ACO1 no. 20 & 3.73 & 1.0 & 2.65 & 0.65 & 0.10 & 0.10 & 0.10 & 45.3 \\
\hline
\end{tabular}

Acids: ICA—isocitric acid, AA—acetic acid, CA—citric acid, KGA— $\alpha$-ketoglutaric acid, SA—succinic acid, MA—malic acid, FA—fumaric acid. All the data presented are the mean values of three experiments and two measurements for each experiment (SD $<10 \%)$. 


\subsection{Effect of Growth-Limiting Component of Cultivation Media}

As seen from Table 2, the strain Y. lipolytica VKM Y-2373 growing in the complete medium with EAF did not produce acids. However, the limitation of its growth by either of the biogenic elements $\mathrm{N}, \mathrm{P}$, and $\mathrm{S}$ led to excretion of ICA and CA in the ratio varied from 1.7:1 to 1.3:1. The limitation of its growth by $\mathrm{Mg}$ increased the ICA:CA ratio to 3.4:1, however, the amount of excreted ICA was 2.7 times lower than under nitrogen deficiency. Under deficiency of $\mathrm{Fe}^{2+}(0.001 \mathrm{mg} / \mathrm{L})$ or $\mathrm{Ca}^{2+}(0.136 \mathrm{mg} / \mathrm{L})$, ICA and CA were not produced, although $\mathrm{Fe}^{2+}$ caused the formation of AA in a noticeable amount $(1.25 \mathrm{~g} / \mathrm{L})$. The maximum ICA production $(6.33 \mathrm{~g} / \mathrm{L})$ with a product yield $\left(\mathrm{Y}_{\text {ICA }}\right)(0.32 \mathrm{~g} / \mathrm{g})$ were observed in the case of nitrogen limitation. Moreover, yeast cells require nitrogen in greater amounts than other nutrient elements $(\mathrm{P}, \mathrm{S}, \mathrm{Mg})$ and, hence, the deficiency of this element in the culture medium can easily be controlled. For this reason, further experiments were carried out with the limitation of yeast growth by a nitrogen source.

Table 2. Effect of limiting component on the growth of Y. lipolytica VKM Y-2373 and ICA production.

\begin{tabular}{|c|c|c|c|c|c|c|c|}
\hline \multirow{2}{*}{ Parameters } & \multirow{2}{*}{$\begin{array}{c}\text { Full Medium }(\mathrm{mg} / \mathrm{L}) \\
\mathrm{N}-630, \mathrm{P}-246 \\
\mathrm{~S}-186, \mathrm{Mg}-140 \\
\mathrm{Ca}-68, \mathrm{Fe}-0.05\end{array}$} & \multicolumn{6}{|c|}{ Limiting Component (mg/L) } \\
\hline & & $N(63.0)$ & $P(2.5)$ & $S(1.9)$ & $\operatorname{Mg}(0.28)$ & Ca (0.136) & $\mathrm{Fe}(0.001)$ \\
\hline Biomass $(\mathrm{g} / \mathrm{L})$ & 8.9 & $2.33 \pm 0.40$ & $1.77 \pm 0.15$ & $1.67 \pm 0.15$ & $2.10 \pm 0.20$ & $1.03 \pm 0.21$ & $1.05 \pm 0.25$ \\
\hline $\mathrm{ICA}(\mathrm{g} / \mathrm{L})$ & 0 & $6.33 \pm 0.32$ & $5.27 \pm 0.15$ & $5.65 \pm 0.25$ & $2.37 \pm 0.21$ & 0 & 0 \\
\hline $\mathrm{CA}(\mathrm{g} / \mathrm{L})$ & 0 & $3.70 \pm 0.20$ & $3.43 \pm 0.31$ & $4.37 \pm 0.21$ & $0.70 \pm 0.10$ & 0 & 0 \\
\hline $\mathrm{AA}(\mathrm{g} / \mathrm{L})$ & 0 & $\operatorname{Tr}$ & $\operatorname{Tr}$ & $\operatorname{Tr}$ & $\operatorname{Tr}$ & 0 & $1.25 \pm 0.32$ \\
\hline ICA/CA ratio & - & $1.7: 1$ & $1.5: 1$ & $1.3: 1$ & $3.4: 1$ & - & - \\
\hline $\mathrm{Y}_{\text {ICA }}(\mathrm{g} / \mathrm{g})$ & - & 0.32 & 0.26 & 0.30 & 0.11 & - & - \\
\hline
\end{tabular}

"Tr" stands for trace amount.

\subsection{Effect of Nitrogen Source}

As seen from Table 3, the best source of nitrogen was found to be urea $\left(\left(\mathrm{NH}_{2}\right)_{2} \mathrm{CO}\right)$ and ammonium sulfate $\left(\left(\mathrm{NH}_{4}\right)_{2} \mathrm{SO}_{4}\right)$ (biomass of 2.35 and $2.33 \mathrm{~g} / \mathrm{L}$, respectively), but ammonium acetate $\left(\mathrm{CH}_{3} \mathrm{COONH}_{4}\right)$ was unable to support the growth of $Y$. lipolytica VKM Y-2373 (biomass of $1.19 \mathrm{~g} / \mathrm{L}$ ).

Table 3. Effect of nitrogen source on the growth of Y. lipolytica VKM Y-2373 and ICA production.

\begin{tabular}{|c|c|c|c|c|c|}
\hline \multirow{2}{*}{ Parameters } & \multicolumn{5}{|c|}{ Nitrogen Concentration (63 mg/L) } \\
\hline & $\left(\mathrm{NH}_{4}\right)_{2} \mathrm{SO}_{4}$ & $\left(\mathrm{NH}_{2}\right)_{2} \mathrm{CO}$ & $\mathrm{NH}_{4} \mathrm{CL}$ & $\mathrm{NH}_{4} \mathrm{NO}_{3}$ & $\mathrm{CH}_{3} \mathrm{COONH}_{4}$ \\
\hline Biomass $(\mathrm{g} / \mathrm{L})$ & $2.33 \pm 0.04$ & $2.35 \pm 0.31$ & $1.63 \pm 0.16$ & $1.76 \pm 0.14$ & $1.19 \pm 0.03$ \\
\hline $\mathrm{ICA}(\mathrm{g} / \mathrm{L})$ & $6.33 \pm 0.32$ & $5.90 \pm 0.15$ & $5.01 \pm 0.28$ & $4.43 \pm 0.39$ & $2.03 \pm 0.15$ \\
\hline $\mathrm{CA}(\mathrm{g} / \mathrm{L})$ & $3.70 \pm 0.20$ & $3.52 \pm 0.19$ & $3.07 \pm 0.21$ & $2.93 \pm 0.15$ & $1.77 \pm 0.21$ \\
\hline $\mathrm{AA}(\mathrm{g} / \mathrm{L})$ & 0.5 & $\operatorname{Tr}$ & 0.5 & $\operatorname{Tr}$ & $\operatorname{Tr}$ \\
\hline ICA/CA ratio & $1.7: 1$ & $1.7: 1$ & $1.6: 1$ & $1.5: 1$ & $1.2: 1$ \\
\hline $\mathrm{Y}_{\text {ICA }}(\mathrm{g} / \mathrm{g})$ & 0.32 & 0.30 & 0.25 & 0.22 & 0.10 \\
\hline
\end{tabular}

Nitrogen source influenced not only yeast growth, but also the production of ICA. The production was at the maximum $(6.33 \mathrm{~g} / \mathrm{L})$ with $\left(\mathrm{NH}_{4}\right)_{2} \mathrm{SO}_{4}$. With $\left(\mathrm{NH}_{2}\right)_{2} \mathrm{CO}$ the ICA production was slightly lower $(5.9 \mathrm{~g} / \mathrm{L})$. With $\mathrm{NH}_{4} \mathrm{Cl}$ and $\mathrm{NH}_{4} \mathrm{NO}_{3}$, the ICA production decreased by $21 \%$ and $30 \%$, respectively, in comparison with the growth limitation by $\left(\mathrm{NH}_{4}\right)_{2} \mathrm{SO}_{4} \cdot \mathrm{CH}_{3} \mathrm{COONH}_{4}$ was found to be the worst nitrogen source for ICA production 
$(2.03 \mathrm{~g} / \mathrm{L})$. The ICA to CA ratio varied from 1.2:1 to 1.7:1 depending on the nitrogen source used. The maximum shift toward the formation of ICA and the maximum product yield $\left(\mathrm{Y}_{\mathrm{ICA}}=0.32 \mathrm{~g} / \mathrm{g}\right)$ was observed in the case of growth limitation by $\left(\mathrm{NH}_{4}\right)_{2} \mathrm{SO}_{4}$.

\subsection{Effect of $p H$}

The growth of Y. lipolytica VKM Y-2373 in media with EAF without titration was accompanied by a drastic fall of $\mathrm{pH}$ (down to 2) by the end of cultivation (Table 4) which was caused by consumption of the cation of physiologically acidic salt $\left(\mathrm{NH}_{4}\right)_{2} \mathrm{SO}_{4}$ and the accumulation of excreted organic acids in the medium. In this case, the production of ICA and CA was low (1.03 and $0.57 \mathrm{~g} / \mathrm{L}$, respectively). In contrast, the regular (daily) alkalization of the growth medium during yeast cultivation by the addition of $10 \mathrm{wt} \% \mathrm{NaOH}$ led to a lower decrease in $\mathrm{pH}$ (down to 5) by the end of cultivation and the accumulation of ICA and CA in greater amounts (6.33 and $3.70 \mathrm{~g} / \mathrm{L}$, respectively). Still, better results were obtained when the medium was supplemented with $2 \mathrm{wt} \% \mathrm{CaCO}_{3}$ just after inoculation of the medium. This approach allowed us to maintain the $\mathrm{pH}$ of the medium at the initial level of 6 during the whole cultivation period. In this case, the production of ICA and CA increased to 8.3 and $5.53 \mathrm{~g} / \mathrm{L}$, respectively, although the accumulation of cell biomass even slightly decreased. The increase of $\mathrm{CaCO}_{3}$ concentration to $3 \mathrm{wt} \%$ did not enhance the production of ICA.

Table 4. Effect of medium titration on Y. lipolytica VKM Y-2373 growth and ICA production.

\begin{tabular}{|c|c|c|c|c|}
\hline \multirow{2}{*}{ Parameters } & \multirow{2}{*}{ Without Titration } & \multicolumn{3}{|c|}{ Titration } \\
\hline & & $10 w t \% \mathrm{NaOH}$ & $2 \mathrm{wt} \% \mathrm{CaCO}_{3}$ & $3 w_{t} \% \mathrm{CaCO}_{3}$ \\
\hline Initial pH & 6.0 & 6.0 & 6.0 & 6.5 \\
\hline Final pH & 2.0 & 5.0 & 6.0 & 6.5 \\
\hline Biomass (g/L) & $1.50 \pm 0.10$ & $2.33 \pm 0.04$ & $1.90 \pm 0.10$ & $1.80 \pm 0.10$ \\
\hline $\mathrm{ICA}(\mathrm{g} / \mathrm{L})$ & $1.03 \pm 0.15$ & $6.33 \pm 0.32$ & $8.30 \pm 0.30$ & $9.00 \pm 0.26$ \\
\hline $\mathrm{CA}(\mathrm{g} / \mathrm{L})$ & $0.57 \pm 0.12$ & $3.70 \pm 0.20$ & $5.53 \pm 0.15$ & $6.03 \pm 0.65$ \\
\hline $\mathrm{AA}(\mathrm{g} / \mathrm{L})$ & 0.5 & 0.5 & 0.1 & 0.1 \\
\hline ICA/CA ratio & $1.8: 1$ & $1.7: 1$ & $1.5: 1$ & $1.5: 1$ \\
\hline $\mathrm{Y}_{\mathrm{ICA}}(\mathrm{g} / \mathrm{g})$ & 0.05 & 0.32 & 0.42 & 0.45 \\
\hline
\end{tabular}

"Tr" stands for trace amount.

Further experiments were designed in order to understand in more detail the dependence of ICA biosynthesis on the $\mathrm{pH}$ of the cultivation medium. For this purpose, $1 \mathrm{M}$ phosphate buffer with $\mathrm{pH}$ varied from 4 to 7 was added to the cultivation medium in an amount of $20 \mathrm{vol} \%$. If the $\mathrm{pH}$ of the medium during cultivation shifted from the set value, it was corrected by the addition of either $\mathrm{NaOH}$. $\mathrm{NaOH}$, rather than other titrants, was chosen because it provided the maximum shift toward the formation of ICA.

The experiments showed that $\mathrm{pH}$ values from 4 to 6.5 are beneficial for yeast growth (Table 5). The range of $\mathrm{pH}$ values favorable for ICA production was narrower. At $\mathrm{pH}$ equal to 4.0 , the production of ICA was low $\left(3.04 \mathrm{~g} / \mathrm{L} \mathrm{ICA}, \mathrm{Y}_{\mathrm{ICA}}=0.15 \mathrm{~g} / \mathrm{g}\right)$. The maximum production of ICA (9.5 and $9.0 \mathrm{~g} / \mathrm{L}$, respectively), was observed at the $\mathrm{pH}$ values of 6.0 and 6.5. 
Table 5. Effect of $\mathrm{pH}$ medium on the growth of Y. lipolytica VKM Y-2373 and ICA production.

\begin{tabular}{cccccccc}
\hline \multirow{2}{*}{ Parameters } & \multicolumn{7}{c}{$\mathbf{p H}$} \\
\cline { 2 - 7 } & $\mathbf{4 . 0}$ & $\mathbf{4 . 5}$ & $\mathbf{5 . 0}$ & $\mathbf{5 . 5}$ & $\mathbf{6 . 0}$ & $\mathbf{6 . 5}$ & $\mathbf{7 . 0}$ \\
\hline Biomass (g/L) & $2.76 \pm 0.12$ & $2.70 \pm 0.26$ & $2.60 \pm 0.10$ & $2.45 \pm 0.10$ & $2.30 \pm 0.10$ & $2.15 \pm 0.10$ & $2.00 \pm 0.11$ \\
\hline ICA (g/L) & $3.04 \pm 0.09$ & $5.90 \pm 0.20$ & $6.59 \pm 0.19$ & $8.00 \pm 0.23$ & $9.50 \pm 0.26$ & $9.00 \pm 0.10$ & $7.31 \pm 0.20$ \\
\hline CA (g/L) & $1.90 \pm 0.17$ & $3.67 \pm 0.15$ & $3.88 \pm 0.11$ & $4.53 \pm 0.13$ & $5.16 \pm 0.15$ & $5.05 \pm 0.21$ & $4.53 \pm 0.13$ \\
\hline AA (g/L) & 0.1 & 0.1 & 0.1 & 0.1 & 0.1 & 0.1 & 0.1 \\
\hline ICA/CA ratio & $1.6: 1$ & $1.6: 1$ & $1.7: 1$ & $1.8: 1$ & $1.8: 1$ & $1.8: 1$ & $1.6: 1$ \\
\hline
\end{tabular}

\subsection{Effect of EAF Concentration}

EAF was added to the growth medium in the fermentor in the portions varied from 1 to $10 \mathrm{~g} / \mathrm{L}$. As seen from Table 6, the content of EAF in the medium weakly influenced the growth of Y. lipolytica VKM Y-2373, so that the accumulation of cell biomass was between 13 and $14.5 \mathrm{~g} / \mathrm{L}$. At the same time, the quantitative composition of excreted organic acids greatly depended on the EAF concentration. Indeed, at the EAF concentration equal to $1 \mathrm{~g} / \mathrm{L}$, the yeast strain synthesized ICA and CA in equal amounts (ICA:CA $=1: 1$ ) and the concentration of AA did not exceed $0.5 \mathrm{~g} / \mathrm{L}$. The increase in the concentration of EAF from 1 to $4 \mathrm{~g} / \mathrm{L}$ promoted the production of ICA from 51.5 to $60.7 \mathrm{~g} / \mathrm{L}$ and suppressed the production of CA from 51.3 to $31.3 \mathrm{~g} / \mathrm{L}$, so that the ICA:CA ratio became 2:1. The increase in the concentration of EAF from 4 to $6 \mathrm{~g} / \mathrm{L}$ slightly suppressed the production of both ICA and CA (to 54.1 and $27.0 \mathrm{~g} / \mathrm{L}$, respectively). The concentration of EAF equal to $10 \mathrm{~g} / \mathrm{L}$ greatly suppressed the formation of ICA $(22.2 \mathrm{~g} / \mathrm{L})$ and CA $(16.0 \mathrm{~g} / \mathrm{L})$ and promoted the accumulation of AA in the medium to $12 \mathrm{~g} / \mathrm{L}$. The maximum values of volume productivity $\left(\mathrm{Q}_{\mathrm{ICA}}=0.89 \mathrm{~g}\right.$ ICA $\left./ \mathrm{L} \cdot \mathrm{h}\right)$ and product yield $\left(\mathrm{Y}_{\mathrm{ICA}}=0.61 \mathrm{~g} / \mathrm{g}\right)$ were observed when EAF was added to the medium in the concentration of $4 \mathrm{~g} / \mathrm{L}$.

Table 6. Effect of EAF on the growth of Y. lipolytica VKM Y-2373 and ICA production.

\begin{tabular}{cccccc}
\hline \multirow{2}{*}{ Parameters } & \multicolumn{5}{c}{ EAF Content, Periodically Added to the Cultivation Medium (g/L) } \\
\cline { 2 - 6 } & $\mathbf{1}$ & $\mathbf{2}$ & $\mathbf{4}$ & $\mathbf{6}$ & $\mathbf{1 0}$ \\
\hline Biomass (g/L) & $13.0 \pm 0.2$ & $13.6 \pm 1.2$ & $13.3 \pm 0.4$ & $14.5 \pm 0.2$ & $14.1 \pm 1.3$ \\
\hline ICA $(\mathrm{g} / \mathrm{L})$ & $51.5 \pm 5.2$ & $56.6 \pm 4.4$ & $60.7 \pm 2.1$ & $54.1 \pm 3.5$ & $22.2 \pm 1.1$ \\
\hline $\mathrm{CA}(\mathrm{g} / \mathrm{L})$ & $51.3 \pm 2.1$ & $33.4 \pm 1.2$ & $31.1 \pm 2.2$ & $27.0 \pm 2.0$ & $16.0 \pm 1.1$ \\
\hline $\mathrm{AA}(\mathrm{g} / \mathrm{L})$ & 0.5 & 0.5 & 0.5 & 0.5 & $12.0 \pm 1.4$ \\
\hline ICA/CA ratio & $1: 1$ & $1.7: 1$ & $2: 1$ & $2: 1$ & $1.4: 1$ \\
\hline $\mathrm{Y}_{\text {ICA }}(\mathrm{g} / \mathrm{g})$ & 0.47 & 0.55 & 0.61 & 0.53 & 0.25 \\
\hline $\mathrm{Q}_{\text {ICA }}(\mathrm{g} / \mathrm{L} \cdot \mathrm{h})$ & 0.78 & 0.81 & 0.89 & 0.81 & 0.31 \\
\hline
\end{tabular}

\subsection{Dynamics of Yeast Growth and Acid Excretion}

The dynamics of growth of Y. lipolytica VKM Y-2373 and acid excretion were studied using cultivation in the fermentor. Cell growth was limited by shortage of the nitrogen source $\left(\left(\mathrm{NH}_{4}\right)_{2} \mathrm{SO}_{4}=3 \mathrm{~g} / \mathrm{L}\right)$. The growth substrate EAF was added in portions varied from 2 to $6 \mathrm{~g} / \mathrm{L}$. The concentration of dissolved oxygen comprised $60 \%$ (of air saturation); $\mathrm{pH}$ was maintained at the level of 6.0.

As seen from Figure 1, the growth curve of Y. lipolytica VKM Y-2373 had a clear-cut exponential phase (to $12 \mathrm{~h}$ of growth), a phase of growth retardation (from 12 to $24 \mathrm{~h}$ of growth), and then a stationary phase. The maximum specific growth rate $\left(\mu_{\max }=0.282 \mathrm{~h}^{-1}\right)$ was observed at $6 \mathrm{~h}$ of cultivation. The excretion of ICA and CA began during the transition of the yeast culture from exponential growth to retarded growth, when the specific growth rate $(\mu)$ fell by two times from its maximum value. In the late phase of retarded growth 
and stationary phase, the yeast strain continued to synthesize ICA and CA with a specific rate of synthesis ( q ICA ) equal to $0.08-0.083 \mathrm{~g} / \mathrm{g} \cdot \mathrm{h}$; beginning from $60 \mathrm{~h}$ of growth, the rate of ICA synthesis decreased by 2 times. By the end of the cultivation period, the culture liquid contained $65.0 \mathrm{~g} / \mathrm{L}$ ICA and $31.2 \mathrm{~g} / \mathrm{L}$ CA with the ICA:CA ratio equal to 2.1:1. The maximum values of volume productivity ( $\mathrm{Q}_{\mathrm{ICA}}$ ) and product yield ( $\mathrm{Y}_{\mathrm{ICA}}$ ) were $0.95 \mathrm{~g}$ ICA $/ \mathrm{L} \cdot \mathrm{h}$ and $0.65 \mathrm{~g} / \mathrm{g}$, respectively.

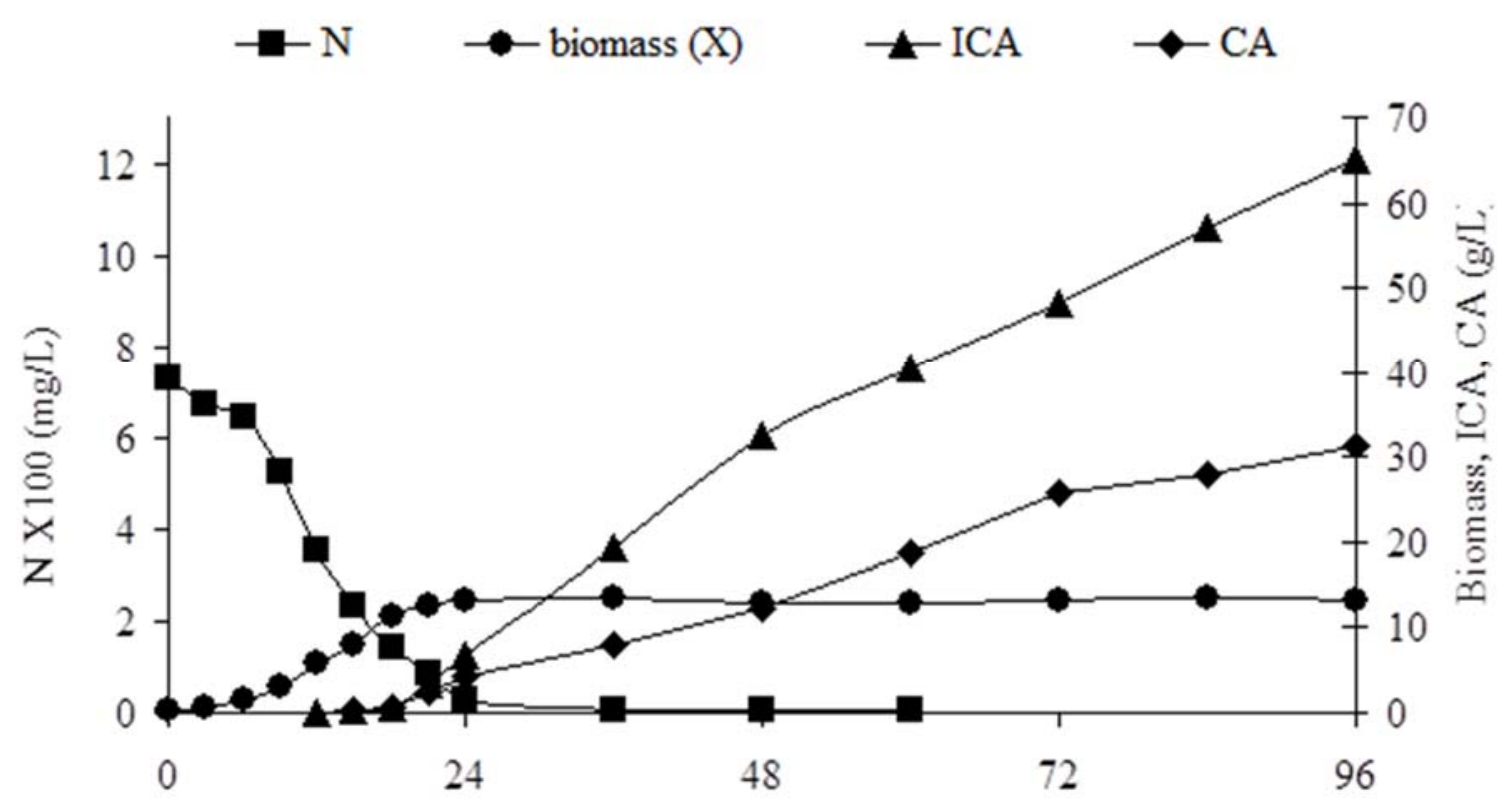

Time (h)

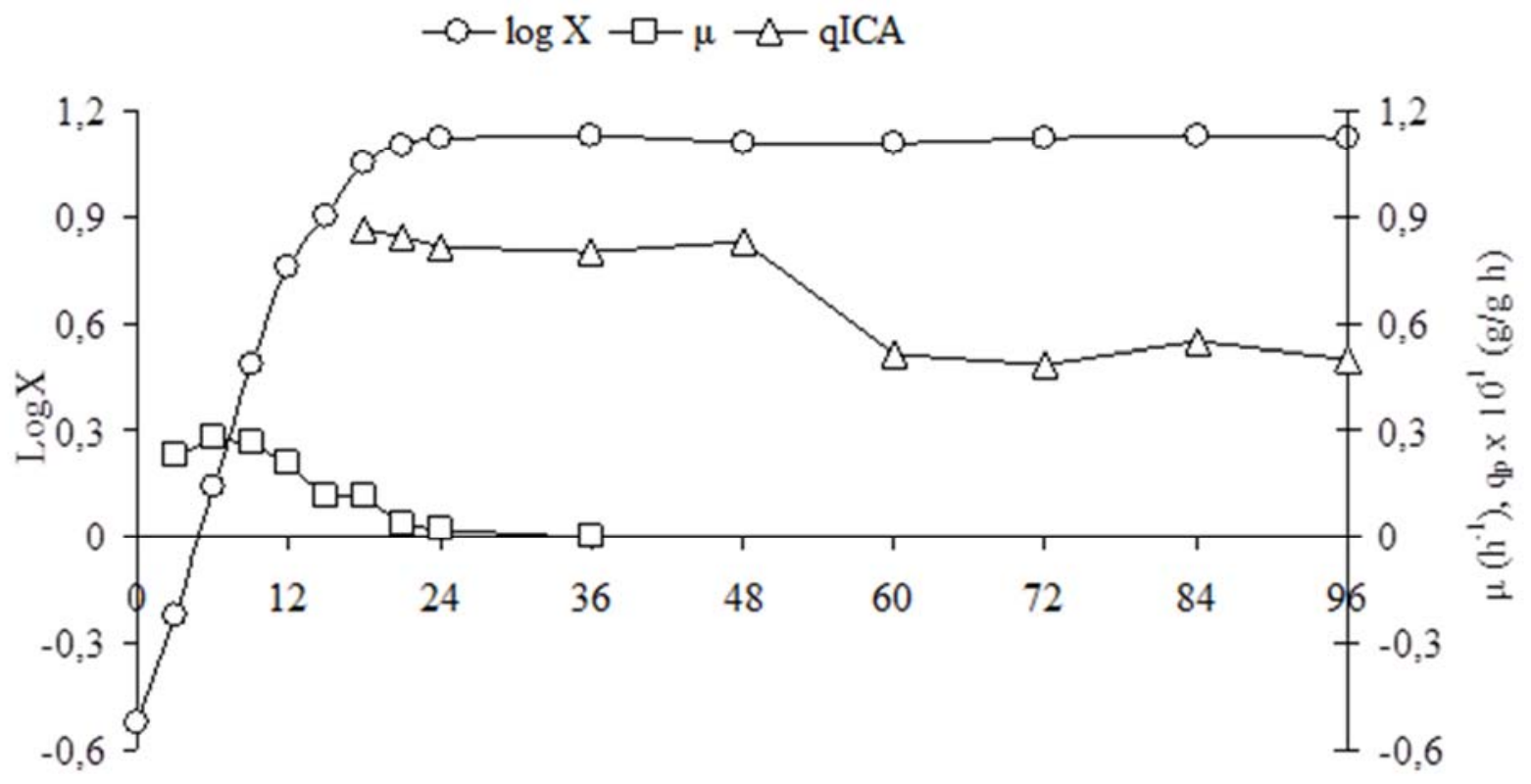

Time (h)

Figure 1. Time course of growth of Y. lipolytica VKM Y-2373, nitrogen consumption, citric acids production in the medium with EAF (top) and the calculated parameters of ICA production (bottom). N—nitrogen; ICA—isocitric acid; CA—citric acid; $\log X$ - logarithm of biomass; $\mu$ —the specific growth rate; qICA — the specific rate of ICA synthesis. 


\section{Discussion}

The results obtained revealed the possibility to use a cheap hard-to-recycle wasteEAF for the microbial production of ICA by yeast strains.

ICA production from EAF was observed in 26 strains (Table 1), but the maximum ICA concentration and the relative content was indicated in the wild-type strain Y. lipolytica VKM Y-2373.

The following peculiarities of ICA production from EAF by the selected strain were revealed.

The strain Y. lipolytica VKM Y-2373 cultivated in the complete nutrient medium showed good growth but without excretion of organic acids. The basic condition of excretion of ICA and CA from EAF was the limitation of Y. lipolytica VKM Y-2373 growth by shortage of nitrogen source (as well as sources of phosphorus, sulfur, or magnesium). The limitation of the strain growth by $\mathrm{Ca}^{2+}$ ions did not cause acid excretion, while the $\mathrm{Fe}^{2+}$ ions deficiency stimulated the excretion of acetic acid, but not ICA or CA (Table 2). It should be noted that the limitation of culture growth by shortage of biogenic elements is a common approach to stimulation of the excretion of organic acids. For example, the excretion of CA by $Y$. lipolytica was stimulated by deficiency of $\mathrm{N}$ and $\mathrm{P}$ [29-31]; the excretion of itaconic acid by Aspergillus terreus was stimulated by P shortage [32,33]; and the excretion of gluconic acid by Aspergillus niger was stimulated by shortage of $\mathrm{N}$ and $\mathrm{P}$ [34]. The most part of studies concerned the biosynthesis of ICA and CA by Y. lipolytica was performed under conditions of nitrogen deficiency $[15-17,22,23,35]$. On the other hand, some authors reported that the addition of $0.7 \mathrm{~g} / \mathrm{L}\left(\mathrm{NH}_{4}\right)_{2} \mathrm{SO}_{4}$ to the medium with the glycerol-containing wastes from biodiesel production shifts the biosynthesis of citric acids toward the preferential synthesis of ICA, as is evident from the shift of the CA:ICA ratio from 1.2:1 to 1:11.5 [26].

Y. lipolytica VKM Y-2373 was found to be able assimilate all nitrogen sources investigated, including inorganic and organic forms. However, it should be noted that the most suitable nitrogen source is ammonium sulfate because it provides the maximum ICA production and its concentration can easily be controlled (Table 3). In experiments with the wide ICA-producing strains of Y. lipolytica grown in media with rapeseed oil, glycerol, glucose, and ethanol as the carbon sources, the authors usually employed $\mathrm{NH}_{4} \mathrm{Cl}$ or $\left(\mathrm{NH}_{4}\right)_{2} \mathrm{SO}_{4}$ as the nitrogen source [22,35]. In experiments with the recombinant strains $Y$. lipolytica CIT 1 and CIT 2 with the super-expressed citrate synthase genes, the authors used $\mathrm{NH}_{4} \mathrm{Cl}$ as the nitrogen source when the strains were grown on glycerol, while $\left(\mathrm{NH}_{4}\right)_{2} \mathrm{SO}_{4}$ when the strains were grown on vegetable oils [19].

The strain Y. lipolytica VKM Y-2373 is able to grow in a range of $\mathrm{pH}$ values from 2 to 6.5 (Table 4). The optimal $\mathrm{pH}$ for growth of this strain does not coinside with the optimal $\mathrm{pH}$ for ICA production (6.0-6.5) (Table 5). This data corresponds to our earlier data that ICA is optimally produced by this strain at $\mathrm{pH}=6.0$ when it is grown in media with rapeseed oil [17], ethanol [16], and biodiesel wastes [10]. Literature data clearly demonstrate the metabolic flexibility of the yeast species $Y$. lipolytica on $\mathrm{pH}$, depending on the particular strain and the carbon source used. Moeller et al. (2007) reported that the production of ICA increases with the $\mathrm{pH}$ value and reaches the maximum at $\mathrm{pH} 7.5$ [35]. At the same time, Papanikolaou et al. (2002) showed that ICA synthesis does not depend on $\mathrm{pH}$ [36]. There is evidence that the genetically modified strains of $Y$. lipolytica with the superexpressed GUT1/GUT2 genes cultivated in media with biodiesel wastes efficiently produced ICA and $\mathrm{CA}$ even at $\mathrm{pH}=3$ and thus did not require the addition of a neutralizing agent [27]. This feature can significantly reduce the profitability of the process. It should be noted that the cultivation of the wide strains of Y. lipolytica at $\mathrm{pH}$ values of 2.5-3.5 generally caused the accumulation of polyols [37,38], while its cultivation at $\mathrm{pH}=4.5-6.0$ led to the accumulation of citric acids [37-39].

EAF in elevated concentrations may suppress the growth and acid formation by Y. lipolytica VKM Y-2373 (Table 6). For this reason, EAF should be added to the culture medium in small portions $(2-6 \mathrm{~g} / \mathrm{L})$ rather than in bulk. The specified value of such portions for EAF is considerably lower than for glucose $(120 \mathrm{~g} / \mathrm{L})$ [35]. Still greater portions 
of the carbon source glycerol (up to $150 \mathrm{~g} / \mathrm{L}$ ) can be used in the case of the transformant Y. lipolytica A101.1.31 with the super-expressed genes CIT1 and CIT2 encoding citrate synthase [19].

Under optimized cultivation conditions, Y. lipolytica VKM Y-2373 grown on EAF produced $65.0 \mathrm{~g} / \mathrm{L}$ ICA with the ICA:CA ratio equal to $2.1: 1$ and product yield $\mathrm{Y}_{\mathrm{ICA}}=0.65 \mathrm{~g} / \mathrm{g}$. The same strain grown on pure ethanol produced $90.5 \mathrm{~g} / \mathrm{L}$ ICA with a product yield of $0.77 \mathrm{~g} / \mathrm{g}$ when cultivated in batch culture [16] and $109.6 \mathrm{~g} / \mathrm{L}$ ICA with a product yield of $0.80 \mathrm{~g} / \mathrm{g}$ when cultivated in repeated-batch culture [8]. Presumably, the reduced biosynthetic activity of Y. lipolytica VKM Y-2373 in media with EAF as the carbon source is associated with harmful impurities (aldehydes, esters, and methanol) in this substance. More efficient processes of ICA production are reported with the use of vegetable oils as the carbon source, which provide the accumulation of 68.4-93 g/L ICA with the product yield $\mathrm{Y}_{\text {ICA }}$ from 0.64 to $0.95 \mathrm{~g} / \mathrm{g}[1,3,4,17,18,20]$. The most efficient process of ICA production was realized using the yeast strain Y. lipolytica YALIOE34672 $\mathrm{g}$ with the enhanced coexpression of the gene coding for the mitochondrial succinate-fumarate carrier YlSfc1 which controls ICA efflux from mitochondria and adenosine monophosphate deaminase YlAMPD genes together with inactivation of citrate mitochondrial carrier YIYHM2 gene. This strain provided the accumulation of $136.7 \mathrm{~g} / \mathrm{L}$ ICA with a process selectivity of $88.1 \%$ [24].

\section{Conclusions}

It was shown for the first time that EAF could be successfully used for the synthesis of ICA by Y. lipolytica yeast. Although the ICA production from EAF $(65 \mathrm{~g} / \mathrm{L}$; product yield $\left(\mathrm{Y}_{\text {ICA }}\right)$ of $0.65 \mathrm{~g} / \mathrm{g}$ ) was lower than that from pure ethanol $(90.5 \mathrm{~g} / \mathrm{L}$; product yield $\left(\mathrm{Y}_{\text {ICA }}\right)$ of $0.77 \mathrm{~g} / \mathrm{g}$ ) [16], EAF can be considered as a promising substrate for microbiological ICA production taking into account its low cost. The optimal fermentation regime which ensures a good growth of selected strain Y. lipolytica VKM Y-2373 and directed synthesis of ICA was determined. It included the limitation of growth by nitrogen; $\left(\mathrm{NH}_{4}\right)_{2} \mathrm{SO}_{4}$ as nitrogen source; $\mathrm{pH}$ values from 4 to 6.5 ; and the addition of EAF by small portions $(2-6 \mathrm{~g} / \mathrm{L})$.

Author Contributions: Conceptualization, S.V.K., V.A.S., I.G.M.; investigation, S.V.K., J.N.L.; methodology, S.V.K.; resources, V.A.S., I.G.M.; supervision, I.G.M.; writing—original draft, S.V.K. All authors have read and agreed to the published version of the manuscript.

Funding: This research received no external funding.

Institutional Review Board Statement: Not applicable.

Informed Consent Statement: Not applicable.

Data Availability Statement: Data is contained within the article.

Conflicts of Interest: The authors declare no conflict of interest.

\section{References}

1. Heretsch, P.; Thomas, F.; Aurich, A.; Krautscheid, H.; Sicker, D.; Giannis, A. Syntheses with a chiral building block from the citric acid cycle: (2R,3S)-isocitric acid by fermentation of sunflower oil. Angew. Chem. Int. Ed. Engl. 2008, 47, 1958-1960. [CrossRef] [PubMed]

2. Kulkarni, M.G.; Shaikh, Y.B.; Borhade, A.S.; Dhondge, A.P.; Chavhan, S.W.; Desai, M.P.; Birhade, D.R.; Dhatrak, N.R.; Gannimani, R. The efficient synthesis of (3R,3aS,6aR)-hexahydrofuro[2,3-b]furan-3-ol and its isomers. Tetrahedron Asymmetry 2010, 21, 2394-2398. [CrossRef]

3. Aurich, A.; Specht, R.; Müller, R.A.; Stottmeister, U.; Yovkova, V.; Otto, C.; Holz, M.; Barth, G.; Heretsch, P.; Thomas, F.A.; et al. Microbiologically produced carboxylic acids used as building blocks in organic synthesis. In Reprogramming Microbial Metabolic Pathways. Subcellular Biochemistry; Wang, X., Chen, J., Quinn, P., Eds.; Springer: Dordrecht, The Netherlands, 2012; Volume 64, pp. 391-423. [CrossRef]

4. Aurich, A.; Hofmann, J.; Oltrogge, R.; Wecks, M.; Glaser, R.; Blömer, L.; Mauersberger, S.; Roland, A.; Müller, R.A.; Sicker, D.; et al. Improved isolation of microbiologically produced (2R,3S)-isocitric acid by adsorption on activated carbon and recovery with methanol. Org. Process. Res. Dev. 2017, 21, 866-870. [CrossRef] 
5. Moore, G.L.; Stringham, R.W.; Teager, D.S.; Yue, T.Y. Practical synthesis of the bicyclic darunavir side chain: (3R,3aS,6aR)hexahydrofuro[2,3-b]furan-3-ol from monopotassium isocitrate. Org. Process. Res. Dev. 2017, 21, 98-106. [CrossRef]

6. Yang, J.; Kim, M.J.; Yoon, W.; Kim, E.Y.; Kim, H.; Lee, Y.; Min, B.; Kang, K.S.; Son, J.H.; Park, H.T.; et al. Isocitrate protects DJ-1 null dopaminergic cells from oxidative stress through NADP+-dependent isocitrate dehydrogenase (IDH). PLoS Genet. 2017, 13, e1006975. [CrossRef]

7. Morgunov, I.G.; Karpukhina, O.V.; Kamzolova, S.V.; Samoilenko, V.A.; Inozemtsev, A.N. Investigation of the effect of biologically active threo-Ds-isocitric acid on oxidative stress in Paramecium caudatum. Prep. Biochem. Biotechnol. 2018, 48, 1-5. [CrossRef]

8. Morgunov, I.G.; Kamzolova, S.V.; Karpukhina, O.V.; Bokieva, S.V.; Inozemtsev, A.N. Biosynthesis of isocitric acid in repeated-batch culture and testing of its stress-protective activity. Appl. Microbiol. Biotechnol. 2019, 103, 3549-3558. [CrossRef] [PubMed]

9. Bullin, K.; Hennig, L.; Herold, R.; Krautscheid, H.; Richter, K.; Sicker, D. An optimized method for an (2R,3S)-isocitric acid building block. Mon. Chem. 2019, 150, 247-253. [CrossRef]

10. Morgunov, I.G.; Kamzolova, S.V.; Karpukhina, O.V.; Bokieva, S.V.; Lunina, J.N.; Inozemtsev, A.N. Microbiological production of isocitric acid from biodiesel waste and its effect on spatial memory. Microorganisms 2020, 8, 462. [CrossRef] [PubMed]

11. Fickers, P.; Cheng, H.; Sze, K.; Lin, C. Sugar alcohols and organic acids synthesis in Yarrowia lipolytica: Where Are We? Microorganisms 2020, 8, 574. [CrossRef]

12. Vickery, H.B. A suggested new nomenclature for the isomers of isocitric acid. J. Biol. Chem. 1962, 237, 1739-1741. [CrossRef]

13. Groenewald, M.; Boekhout, T.; Neuvéglise, C.; Gaillardin, C.; Van Dijck, P.W.; Wyss, M. Yarrowia lipolytica: Safety assessment of an oleaginous yeast with a great industrial potential. Crit. Rev. Microbiol. 2014, 40, 187-206. [CrossRef]

14. Zinjarde, S.S. Food-related applications of Yarrowia lipolytica. Food Chem. 2014, 152, 1-10. [CrossRef]

15. Finogenova, T.V.; Shishkanova, N.V.; Fausek, E.A.; Eremina, S.S. Biosynthesis of isocitric acid from ethanol by yeasts. Appl. Microbiol. Biotechnol. 1991, 36, 231-235. [CrossRef]

16. Kamzolova, S.V.; Shamin, R.V.; Stepanova, N.N.; Morgunov, G.I.; Lunina, J.N.; Allayarov, R.K.; Samoilenko, V.A.; Morgunov, I.G. Fermentation conditions and media optimization for isocitric acid production from ethanol by Yarrowia lipolytica. Biomed. Res. Int. 2018, e2543210. [CrossRef]

17. Kamzolova, S.V.; Dedyukhina, E.G.; Samoilenko, V.A.; Lunina, J.N.; Puntus, I.F.; Allayarov, R.K.; Chiglintseva, M.N.; Mironov, A.A.; Morgunov, I.G. Isocitric acid production from rapeseed oil by Yarrowia lipolytica yeast. Appl. Microbiol. Biotechnol. 2013, 97, 9133-9144. [CrossRef]

18. Laptev, I.A.; Filimonova, N.A.; Allayarov, R.K.; Kamzolova, S.V.; Samoilenko, V.A.; Sineoky, S.P.; Morgunov, I.G. New recombinant strains of the yeast Yarrowia lipolytica with overexpression of the aconitate hydratase gene for the obtainment of isocitric acid from rapeseed oil. Appl. Biochem. Microbiol. 2016, 52, 699-704. [CrossRef]

19. Hapeta, P.; Rakicka-Pustułka, M.; Juszczyk, P.; Robak, M.; Rymowicz, W.; Lazar, Z. Overexpression of citrate synthase increases isocitric acid biosynthesis in the heast Yarrowia lipolytica. Sustainability 2020, 12, 7364. [CrossRef]

20. Kamzolova, S.V.; Samoilenko, V.A.; Lunina, J.N.; Morgunov, I.G. Effects of medium components on isocitric acid production by Yarrowia lipolytica yeast. Fermentation 2020, 6, 112. [CrossRef]

21. Finogenova, T.V.; Shishkanova, N.V.; Ermakova, I.T.; Kataeva, I.A. Properties of Candida lipolytica mutants with the modified glyoxylate cycle and their ability to produce citric and isocitric acid. II. Synthesis of citric and isocitric acid by mutants and peculiarities of their enzyme systems. Appl. Microbiol. Biotechnol. 1986, 23, 378-383. [CrossRef]

22. Förster, A.; Jacobs, K.; Juretzek, T.; Mauersberger, S.; Barth, B. Overexpression of the ICL1 gene changes the product ratio of citric acid production by Yarrowia lipolytica. Appl. Microbiol. Biotechnol. 2007, 77, 861-869. [CrossRef] [PubMed]

23. Holz, M.; Förster, A.; Mauersberger, S.; Barth, G. Aconitase overexpression changes the product ratio of citric acid production by Yarrowia lipolytica. Appl. Microbiol. Biotechnol. 2009, 81, 1087-1096. [CrossRef] [PubMed]

24. Yuzbasheva, E.Y.; Scarcia, P.; Yuzbashev, T.V.; Messina, E.; Kosikhina, I.M.; Palmieri, L.; Shutov, A.V.; Taratynova, M.O.; Amaro, R.L.; Palmieri, F.; et al. Engineering Yarrowia lipolytica for the selective and high-level production of isocitric acid through manipulation of mitochondrial dicarboxylate-tricarboxylate carriers. Metab. Eng. 2021, 65, 156-166. [CrossRef] [PubMed]

25. Ermakova, I.T.; Shishkanova, N.V.; Melnikova, O.F.; Finogenova, T.V. Properties of Candida lipolytica mutants with the modified glyoxylate cycle and their ability to produce citric and isocitric acid. I. Physiological, biochemical and cytological characteristics of mutants grown on glucose or hexadecane. Appl. Microbiol. Biotechnol. 1986, 23, 372-377. [CrossRef]

26. Da Silva, L.V.; Tavares, C.B.; Amaral, P.F.F.; Coehlo, M.A.Z. Production of citric acid by Yarrowia lipolytica in different crude oil concentrations and in different nitrogen sources. Chem. Eng. Trans. 2012, 27, 199-204.

27. Rzechonek, D.A.; Dobrowolski, A.; Rymowicz, W.; Mirończuk, A.M. Aseptic production of citric and isocitric acid from crude glycerol by genetically modified Yarrowia lipolytica. Bioresour. Technol. 2019, 271, 340-344. [CrossRef] [PubMed]

28. Barth, G.; Gaillardin, C. Physiology and genetics of the dimorphic fungus Yarrowia lipolytica. FEMS Microbiol. Rev. 1997, 19, 219-237. [CrossRef]

29. Rywińska, A.; Wojtatowicz, M.; Rymowicz, W. Citric acid biosynthesis by Yarrowia lipolytica A-101-1.31 under deficiency of various medium macrocomponents. Electron. J. Pol. Agric. Univ. 2006, 9, 15.

30. Rywińska, A.; Juszczyk, P.; Wojtatowicz, M.; Rymowicz, W. Chemostat study of citric acid production from glycerol by Yarrowia Lipolytica. J. Biotechnol. 2011, 152, 54-57. [CrossRef]

31. Kamzolova, S.V.; Morgunov, I.G. Metabolic peculiarities of the citric acid overproduction from glucose in yeasts Yarrowia lipolytica. Bioresour. Technol. 2017, 243, 433-440. [CrossRef] 
32. Willke, T.; Vorlop, K.D. Biotechnological production of itaconic acid. Appl. Microbiol. Biotechnol. 2001, 56, 289-295. [CrossRef]

33. Karaffa, L.; Kubicek, C.P. Citric acid and itaconic acid accumulation: Variations of the same story? Appl. Microbiol. Biotechnol. 2019, 103, 2889-2902. [CrossRef] [PubMed]

34. Ramachandran, S.; Fontanille, P.; Pandey, A.; Larroche, C. Gluconic acid: Properties, applications and microbial production. Food Technol. Biotech. 2006, 44, 185-195.

35. Moeller, L.; Strehlitz, B.; Aurich, A.; Zehnsdorf, A.; Bley, T. Optimization of citric acid production from glucose by Yarrowia Lipolytica. Eng. Life Sci. 2007, 7, 504-511. [CrossRef]

36. Papanikolaou, S.; Muniglia, L.; Chevalot, I.; Aggelis, G.; Marc, I. Yarrowia lipolytica as a potential producer of citric acid from raw glycerol. J. Appl. Microbiol. 2002, 92, 737-744. [CrossRef] [PubMed]

37. Tomaszewska, L.; Rakicka, M.; Rymowicz, W.; Rywinska, A. A comparative study on glycerol metabolism to erythritol and citric acid in Yarrowia lipolytica yeast cells. FEMS Yeast Res. 2014, 14, 966-976. [CrossRef]

38. Egermeier, M.; Russmayer, H.; Sauer, M.; Marx, H. Metabolic flexibility of Yarrowia lipolytica growing on glycerol. Front. Microbiol. 2017, 8, 49. [CrossRef] [PubMed]

39. Papanikolaou, S.; Beopoulos, A.; Koletti, A.; Thevenieau, F.; Koutinas, A.A.; Nicaud, J.M.; Aggelis, G. Importance of the methyl-citrate cycle on glycerol metabolism in the yeast Yarrowia lipolytica. J. Biotechnol. 2013, 168, 303-314. [CrossRef] 